\title{
Soil Organic Carbon in Forest and Other Land Use Types at Bengkulu City, Indonesia
}

\author{
Wiryono $^{1 *}$, Zainal Muktamar ${ }^{2}$, Deselina ${ }^{1}$, Steffanie Nurliana ${ }^{3}$, Hastari Aningtias ${ }^{1}$, Paka Mutiara Anugrah $^{1}$ \\ ${ }^{1}$ Department of Forestry, Faculty of Agriculture, University of Bengkulu, Jalan WR Supratman, Bengkulu, Indonesia 38371A \\ ${ }^{2}$ Program Study of Soil Science, Faculty of Agriculture, University of Bengkulu, Jalan WR Supratman, Bengkulu, Indonesia \\ $38371 \mathrm{~A}$
}

Received May 29, 2021/Accepted December 3, 2021

\begin{abstract}
Conversion of natural forest into agricultural land uses has decreased soil organic carbon (SOC) and increased carbon emission into the atmosphere, but proper management of agricultural land can sequester carbon from the atmosphere and increase the SOC. This study was conducted to estimate the SOC content and storage in a forest, agroforestry land, oil palm plantation, and agricultural experimental field and to analyze the correlation between the SOC and other soil characteristics at Bengkulu City, Indonesia. Soil were sampled from the following depths: 0-10 cm, 10-20 cm, and 20-30 cm. The biomass of litter and ground cover was also sampled. This study found that the forest had the highest average SOC content from the three depths, and 0-30 cm depth SOC storage, while the agroforestry system had the lowest of both SOC content and storage. The $0-10 \mathrm{~cm}$ depth had the highest SOC content and storage, while the 20-30 cm depth had the lowest of both variables. The SOC was positively correlated with litter biomass, field capacity, exchangeable potassium, cation exchange capacity, and negatively correlated with bulk density and exchangeable calcium, but not correlated with total nitrogen and available phosphorus. High litter biomass input is the key to the maintenance of high SOC.
\end{abstract}

Keywords: agroforestry, litter biomass, palm plantation, carbon sequestration

*Correspondenceauthor,email:wiryonogood@unib.ac.id; wiryono60@gmail.com tel+62-736-31170, fax $+62-736-22105$

\section{Introduction}

A natural forest has a higher capability of storing carbon both in the soil and above ground than most other land uses (Ravindranath \& Ostwald, 2008). When a forest is converted to other land uses, the soil organic carbon (SOC) decreases while carbon emission into the atmosphere increases (Lal, 2020). As much as $1.74 \mathrm{Mg} \mathrm{ha}^{-1}$ year $^{-1}$ of SOC may be lost when a forest is converted to farmland (Deng et al., 2016). In Sulawesi, the conversion of natural forest to oil palm plantation has reduced SOC up to 50\% (van Straaten et al., 2015). In North Sumatera, the conversion of natural forest into agricultural land has reduced SOC up to $93 \%$ (Wasis, 2012). To prevent the SOC from being lost and released into the atmosphere, the most popular method is reducing deforestation and forest degradation. Annually, the tropical primary forest can sequester $813 \%$ of global carbon from anthropogenic emissions (Mackey et al., 2020). Preventing deforestation in developing countries is, however, difficult as the demand for land is increasing. In Indonesia, much of the natural forest has been converted into plantations, mostly oil palm plantations (Khasanah et al., 2015). Another method of preventing carbon loss into the atmosphere is improving soil management because the SOC is larger than other carbon pools in the carbon cycle (Deng et al., 2016). With proper management, soil can sequester a great amount of carbon from the atmosphere and store it. Therefore, during COP2 1 in Paris, France proposed the 4 per 1,000 initiative to boost the sequestration of carbon from better soil management
(Minasny et al., 2017). Inputs of organic carbon for soil include crop residues, decomposed roots, and manure (Navarro-Pedreño et al., 2021). Therefore, the SOC in farmland can be increased by returning plant residues to the soil (Stella et al., 2019) or adding fertilizer, especially manure (Kadlec et al., 2012). The application of biochar can stabilize soil aggregate which in turn may increase the SOC storage (Li et al., 2021). However, the management of soil has no effect on the SOC below $30 \mathrm{~cm}$ depth (Franzluebbers, 2021).

Increasing the SOC not only reduces carbon emission into the atmosphere but also improves soil fertility (FAO, 2017) and crop yield (Oldfield et al., 2019). Increasing the SOC can also increase CEC, water availability, and soil aggregation leading to reduced soil compaction (Murphy, 2015). Due to its important role in improving soil properties, the amount of SOC can be used as a soil sustainability index (Signor et al., 2018). Improving the SOC is, therefore, very important in the tropic regions such as Sumatera which has experienced forest conversion for several decades, including into oil palm plantation. Study of the SOC in different land uses and water characteristic has been done by Hermawan et al., (2020), while Farrasati et al., (2020) has studied the SOC in oil palm plantation and its relation with several chemical properties of soil. So far, no study has been done to correlate the SOC with both physical and chemical properties in forests and other land use types in mineral soil in Sumatera.

This study was done to estimate the SOC content and 
storage in secondary forest, oil palm plantation, agroforestry land, and agricultural experimental field at Bengkulu City, Indonesia, and to analyze the correlation between the SOC and other soil characteristics.

\section{Methods}

Study sites This research was conducted in four land use types, i.e., urban forest, agroforestry land, oil palm plantations, and agricultural experimental field at Bengkulu City, Bengkulu Province, Indonesia (Figure 1 and Figure 2) from July to September 2020. The urban forest (hereafter referred to as forest) is an old ( $>30$ years old) secondary forest located at the University of Bengkulu. The oil palm plantation is approximately 8 years old located in Kandang Limun Village. The agricultural experimental field (hereafter referred to as agricultural field) is a field used by the University of Bengkulu students and faculty members to conduct agricultural experiments with seasonal plants. The agroforestry lands are home gardens consisting of trees, shrubs, and herbs, located in Surabaya Village. Unfortunately, we had no detailed information on their soil types.

Soil sampling Soil sampling for organic carbon is done following the Indonesian National Standard (SNI)-7724 procedure (BSN, 2011) with slight modifications as follows: In one plot, measuring $5 \times 5 \mathrm{~m}$, soil samples were taken from 5 points ( 4 cardinal points plus 1 in the center), at three depths $(0-10 \mathrm{~cm}, 10-20 \mathrm{~cm}$, and $20-30 \mathrm{~cm})$, and then samples from 5 points were combined for each depth. Sampling was repeated 4 times in each land use type with a total of 12 composite soil samples.

The soil samples were air-dried, ground, and sieved using a $2 \mathrm{~mm}$ screen for texture analysis, and a $0.5 \mathrm{~mm}$ screen for other analysis. Soil organic carbon was analyzed using Walkley-Black Method and determined with a spectrophotometer using $561 \mathrm{~nm}$ wavelength and soil $\mathrm{pH}$ using $\mathrm{pH}$ meter with a ratio of soil and distilled water of $1: 2.5$
(Eviati \& Sulaiman, 2009). Soil texture was determined with the hydrometer method (Agus et al., 2006a).

Sampling for the bulk density was done using rings in the plot. In each plot, five samples were taken at each depth, so there were 15 samples for each plot. Total samples for each land use type were 60 . Sampling for field capacity was also done using rings, 3 samples at each depth, with a total of 36 samples for each land use type. More ring samples were taken than composite samples because each composite sample represented five points, while each ring sample represented only one point. Bulk density was determined using the core method (Agus, et al., 2006b), and field capacity using the pressure plate method (Sudirman et al., 2006).

For other soil properties, i.e., total $\mathrm{N}$, available $\mathrm{P}$, exchangeable $\mathrm{K}$, exchangeable $\mathrm{Ca}$, CEC samplings were done only for $0-10 \mathrm{~cm}$ depth, with a total of 16 samples for four land use types. Total soil nitrogen was determined with the Kjeldahl method, phosphorus with Bray I method, potassium with $1 \mathrm{~N}$ NH4O Acetate extraction before was analyzed using a flame photometer, calcium with EDTA titration method, CEC using 1N NH4OAcetate extraction (Eviati \& Sulaiman, 2009). The soil samples were processed and analyzed at the Soil Science Laboratory, Faculty of Agriculture, The University of Bengkulu.

Litter and groundcover biomass sampling In every plot, ground cover and litter were sampled from the same location as the soil sampling, using a frame sizing $1 \times 1 \mathrm{~m}$. All the ground cover within the frame was cut and weighed. All the litter was collected and weighed. In one plot, 4 samples of ground cover and 4 samples of litter were taken, with a total of 64 samples of ground cover and 64 samples of litter for four land use types. Then, from each frame, $300 \mathrm{~g}$ of the ground cover and $300 \mathrm{~g}$ of the litter was put into separate paper bags to be oven-dried until the weight was constant. Then, the oven-dried weight was recorded to determine the biomass.

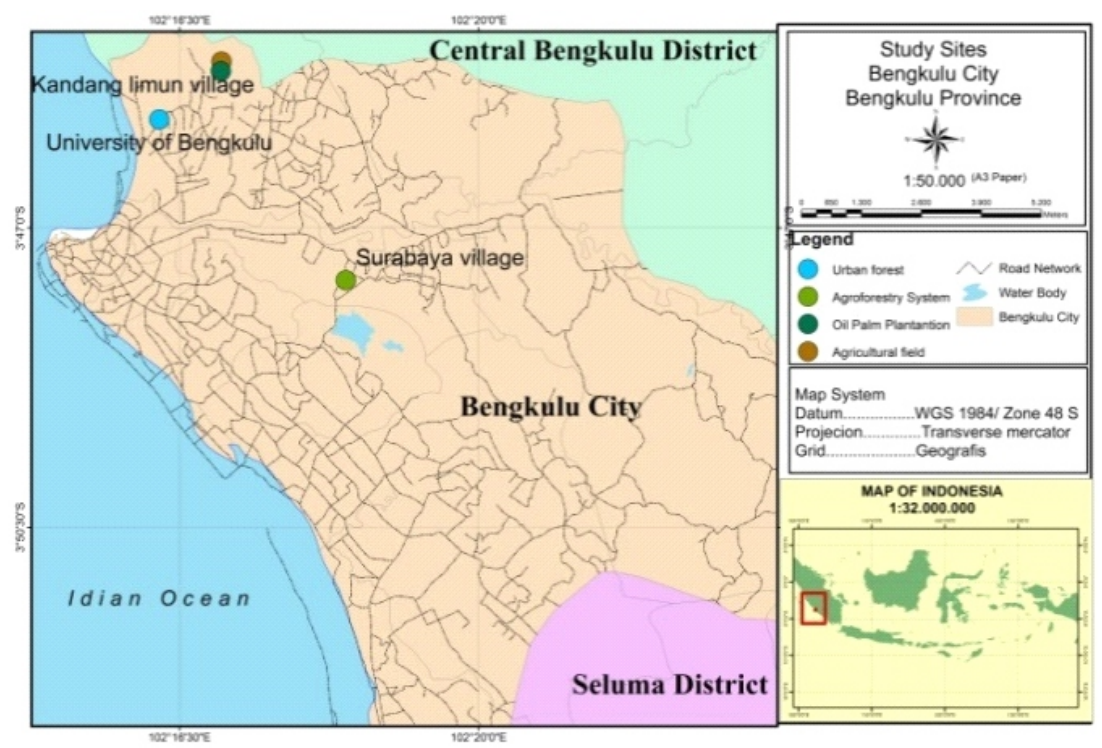

Figure 1 Study sites in Bengkulu City, Indonesia: urban forest, oil palm plantation, agroforestry system, and agricultural field. 

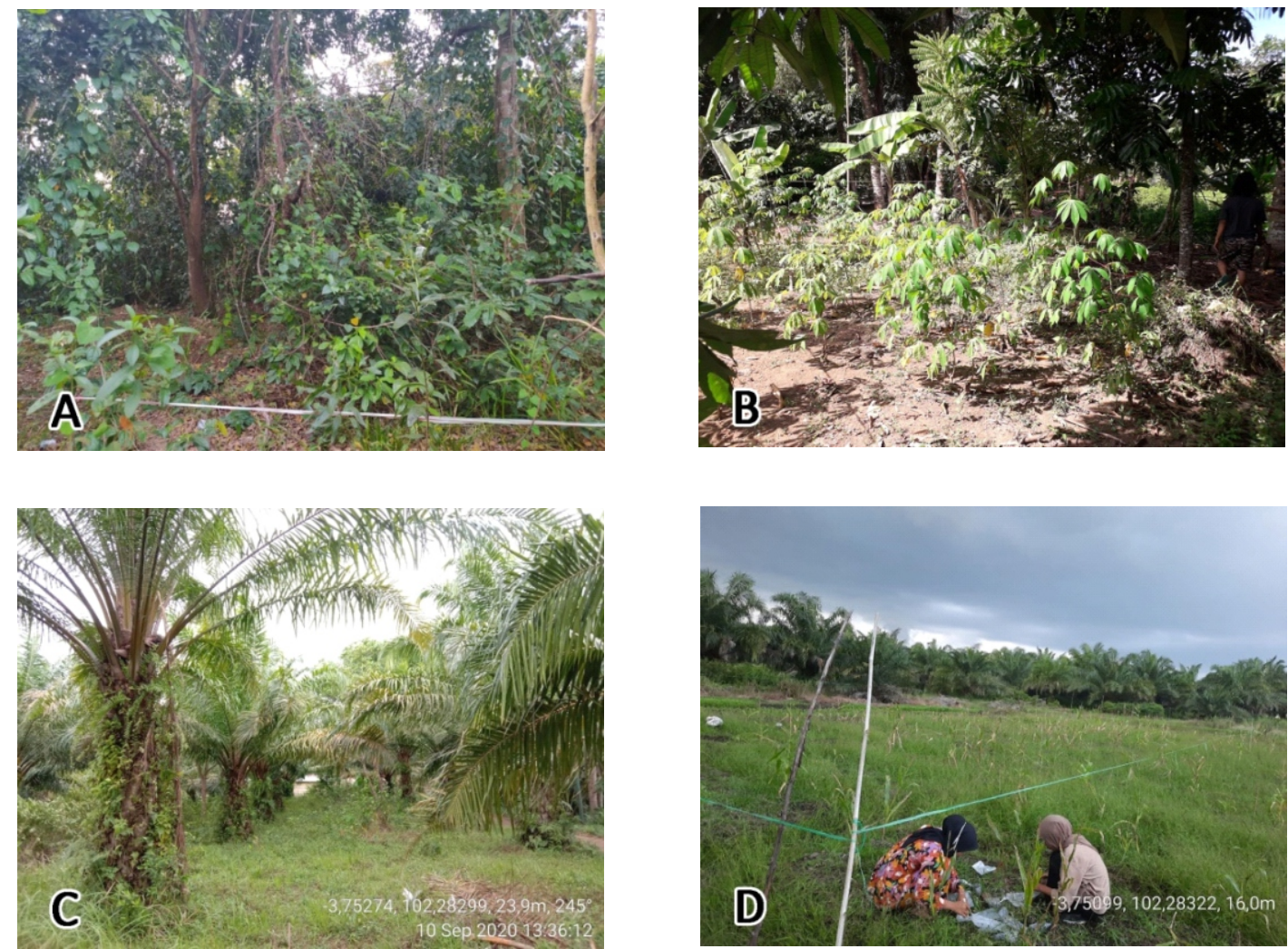

Figure 2 Land use types in the study sites: forest (A), agroforestry (B), oil palm plantation (C), and agricultural experimental field (D).

SOC storage determination Based on the SOC content determined using a spectrophotometer, the SOC storage for certain depth was calculated using the formula as shown in Equation [1] (BSN, 2011).

$\mathrm{Cst}=\mathrm{Sd} \times \rho \times \mathrm{SOC} \times 100$

note: $\mathrm{Cst}=$ soil organic carbon storage $\left(\mathrm{Mg} \mathrm{ha}^{-1}\right) ; \mathrm{Sd}=$ depth of soil $(\mathrm{cm}) ; \rho=$ bulk density $\left(\mathrm{g} \mathrm{cm}^{-3}\right) ; \mathrm{SOC}=$ soil organic carbon concentration.

Statistical analysis The effect of land use types and soil depth on soil characteristics was determined with analyses of variance using Microsoft Excel. When a significant difference was found, then the Least Significant Difference (LSD) test was calculated manually (Steel \& Torie, 1980). Correlation between the SOC content and other soil characteristics was also analyzed.

\section{Results and Discussion}

SOC content and storage in different land use types and soil depths The SOC content and storage were significantly different among land use types and depth (Table 1 and Table 2; Figure 3A and Figure 3B). The forest had the highest average SOC content from 3 depths $(M=4.97 \%, S D=$ $0.81 \%)$, and $0-30 \mathrm{~cm}$ depth SOC storage $(M=157.08$ $\left.\mathrm{Mg} \mathrm{ha}^{-1}, S D=14.79 \mathrm{Mg} \mathrm{ha}^{-1}\right)$, while the agroforestry land had the lowest $\left(M=1.98 \%, S D=0.59 \%\right.$, and $M=70.81 \mathrm{Mg} \mathrm{ha}^{-1}$, $S D=16.85 \mathrm{Mg} \mathrm{ha}^{-1}$, respectively (Table 1).
These results confirm other studies' reports that the forest has relatively higher SOC than other land use types. In the highland of Mexico, the SOC in the $15 \mathrm{~cm}$-depth forest soil was $40.31 \mathrm{Mg} \mathrm{ha}^{-1}$, while the SOC in the same depth of arable land was only $5.9 \mathrm{Mg} \mathrm{ha}^{-1}$ (Fusaro et al., 2019). A study in Tunisia (Jendoubi et al., 2019) found that forests had the SOC of $1.09 \%$ higher than that in crop lands $(0.87 \%)$, grazing lands $(0.74 \%)$, and field crops $(0.70 \%)$. In Sulawesi, the SOC of oil palm plantations was $50 \%$ of that in natural forests (van Straaten et al., 2015). In six countries of Africa, the conversion of forest to cropland caused the loss of $6.7 \mathrm{Mg}$ $\mathrm{ha}^{-1}$ year $^{-1}$. The SOC in the top $30 \mathrm{~cm}$ layer for ten year period (Namirembe et al., 2020).

The higher SOC in the forest was presumably due to the significantly higher litter biomass $\left(M=279.95 \mathrm{~g} \mathrm{~m}^{-2}, S D=\right.$ $41.80 \mathrm{~g} \mathrm{~m}^{-2}$ ) than the other land use types (Table 1). The litter biomass and SOC content were strongly correlated positively $(r=0.84 ; p$-value $<0.0001)$ (Figure 4).

Surprisingly, in this study, the lands utilizing agroforestry system had the lowest SOC, unlike the general notion that the agroforestry system has high SOC. In fact, implementing agroforestry is one of several methods to increase carbon sequestration (Lal, 2020). A meta-analysis found that the lands with agroforestry system in humid and sub-humid tropics can increase their SOC up to $21 \%$ compared to in monoculture system (Muchane, 2020). In Sulawesi, the SOC in the forest was $87 \mathrm{Mg} \mathrm{ha}^{-1}$, and in cocoa agroforestry was $80 \mathrm{Mg} \mathrm{ha}^{-1}$, but those numbers were not statistically different (Kessler et al., 2012). In Chiapas communities in 
Table 1 Soil organic carbon and biomass input in different land use types in the study sites

\begin{tabular}{lcccc}
\hline \multicolumn{1}{c}{ Land use types } & $\begin{array}{c}\text { Average SOC } \\
\text { content }(\%)\end{array}$ & $\begin{array}{c}\text { 0-30 cm-depth SOC } \\
\text { storage }\left(\mathrm{Mg} \mathrm{ha}^{-1}\right)\end{array}$ & $\begin{array}{c}\text { Ground cover biomass } \\
\left(\mathrm{g} \mathrm{m}^{-2}\right)\end{array}$ & $\begin{array}{c}\text { Litter biomass } \\
\left(\mathrm{g} \mathrm{m}^{-2}\right)\end{array}$ \\
\hline Forest & $4.97 \pm 0.81 \mathrm{a}$ & $157.08 \pm 14.79 \mathrm{a}$ & $8.24 \pm 7.21 \mathrm{a}$ & $279.95 \pm 41.80 \mathrm{a}$ \\
Agricultural field & $3.28 \pm 1.42 \mathrm{~b}$ & $113.32 \pm 18.11 \mathrm{~b}$ & $157.26 \pm 105.36 \mathrm{~b}$ & $133.24 \pm 81.65 \mathrm{~b}$ \\
Oil palm plantation & $2.79 \pm 1.19 \mathrm{~b}$ & $91.02 \pm 5.93 \mathrm{bc}$ & $211.72 \pm 63.78 \mathrm{~b}$ & $123.51 \pm 23.71 \mathrm{~b}$ \\
Agroforestry system & $1.98 \pm 0.59 \mathrm{c}$ & $70.81 \pm 16.85 \mathrm{c}$ & $41.43 \pm 30.04 \mathrm{a}$ & $79.30 \pm 27.78 \mathrm{~b}$ \\
\hline
\end{tabular}

Note: Numbers are mean and standard deviation. SOC content: the average values from the three depths: $0-10 \mathrm{~cm} ; 10-20 \mathrm{~cm}$; $20-30 \mathrm{~cm}$. Different letters following values in the same column indicate significant differences among the values ( $p$-value $<$ $0.05)$, determined with Fisher's LSD test.

Table 2 Soil organic carbon content and storage at different depths in the study sites

\begin{tabular}{ccc}
\hline Soil depth $(\mathrm{cm})$ & SOC content $(\%)$ & SOC storage $\left(\mathrm{Mg} \mathrm{ha}^{-1}\right)$ \\
\hline $0-10$ & $4.16 \pm 1.41 \mathrm{a}$ & $44.60 \pm 15.58 \mathrm{a}$ \\
$0-20$ & $3.30 \pm 1.21 \mathrm{a}$ & $36.29 \pm 12.07 \mathrm{~b}$ \\
$20-30$ & $2.31 \pm 1.35 \mathrm{~b}$ & $27.17 \pm 13.74 \mathrm{c}$ \\
\hline
\end{tabular}

Note: Different letters following values in the same column indicate significant differences among the values ( $p$-value $<0.05)$, determined with Fisher's LSD test.

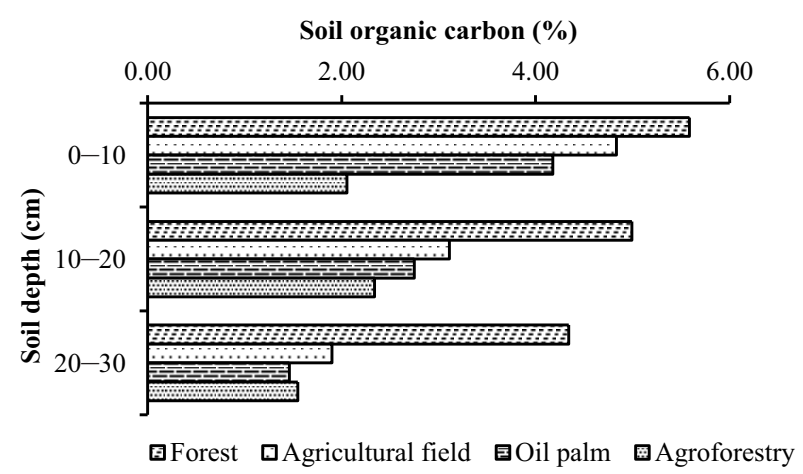

A

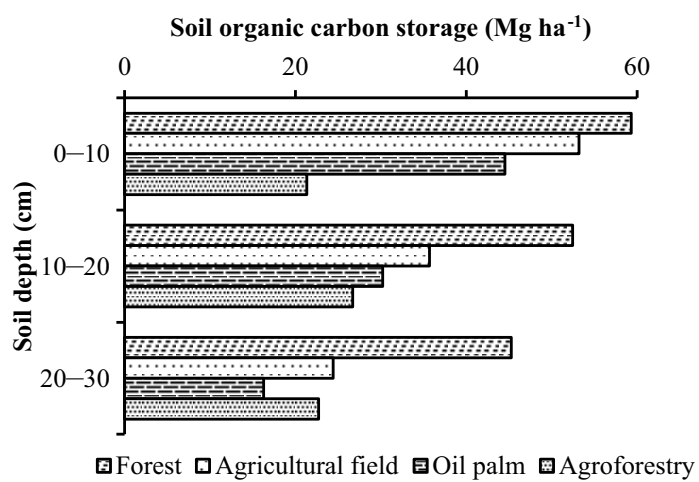

B

Figure 3 Soil organic carbon content (A) and soil organic storage (B) in different land use types and soil depths.

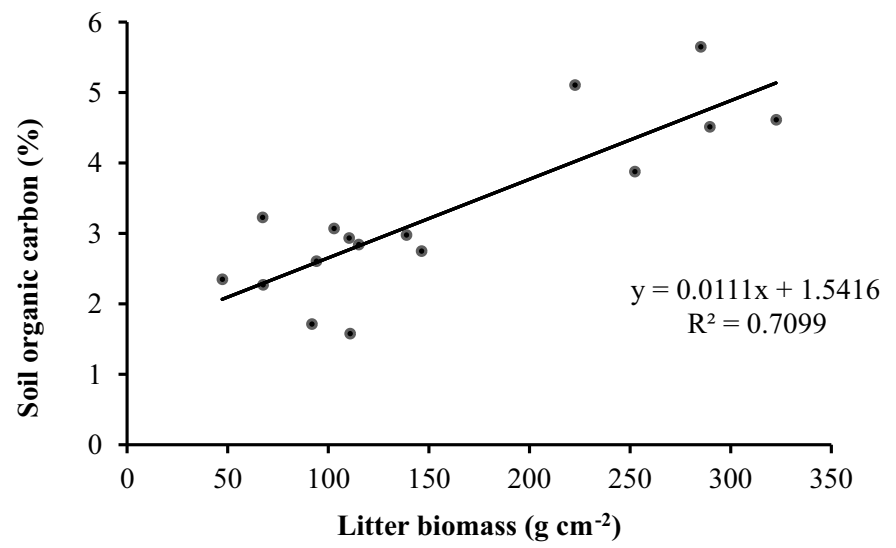

Figure 4 Correlation between SOC and litter biomass in the study sites. 
Mexico, the agroforestry system had higher soil carbon than the traditional maize cultivation and pastures without trees (Soto-Pinto et al., 2010).

The low SOC in the agroforestry system in the present study was presumably due to the lack of litter since the owners usually removed the litter (considered as garbage) from the agroforestry land, which was the home gardens located in the backyard of the houses. The agroforestry had the lowest litter, while the forest had the highest litter biomass (Table 1). The forest litter provided $\mathrm{C}$ input to the soil, thus maintaining high SOC.

In agricultural land, litter biomass from crop residues is one of the inputs of SOC (Navarro-Pedreño et al., 2021), so returning plant residues into the soil is the key to prevent SOC loss in agricultural land (Stella et al., 2019). In this study, the agricultural field which ranked second in the average SOC content and storage also ranked second in litter biomass (Table 1). The field was occasionally left fallow and grown with grass and sedges. Sometimes, it also received manure to improve the crop growth. A study in experimental plots near Prague, Czech Republic, showed that the input of organic matter, especially manure, reduced the SOC loss and increased carbon sequestration (Kadlec et al., 2012). In the Mediterranean cropping system, it was also found that crop residues and manure input were positively correlated with the SOC (Kong et al., 2005).

In the forest, the litter biomass was not contributed by the ground cover, because the forest had the lowest ground cover (Table 1), but by fallen tree leaves. The thick litter in the forest is decomposed into humus and enriches the soil with organic matter which is accumulated mostly in A horizon . It is not surprising, and therefore, the highest SOC content and storage in this study were found in the top layer.

In this study, the highest SOC content $(M=4.16 \%, S D=$ $1.41 \%)$ and storage $\left(M=44.60 \mathrm{Mg} \mathrm{ha}^{-1}, S D=15.58 \mathrm{Mg} \mathrm{ha}^{-1}\right)$ were found in $0-10 \mathrm{~cm}$ depth, the lowest $(2.31 \%$ and 27.17 $\mathrm{Mg} \mathrm{ha}{ }^{-1}$, respectively) were found in $20-30 \mathrm{~cm}$ depth (Table 2). In the agroforestry system of Chiapas communities in Mexico, the values in the same depth intervals also showed a decreasing pattern: $39.7,23.2$, and $18.1 \mathrm{Mg} \mathrm{ha}^{-1}$ (Soto-Pinto et al., 2010). Soil organic carbon also decreased in deeper soil in the upper Yellow River of China (Guo et al., 2016), in the Lancangjiang River Basin, China (Zhou et al., 2020), and the tropical plain in Cameroon (Kome et al., 2021). However, despite having a lower concentration of carbon, deep soil has greater total SOC storage due to its greater soil mass (Gross
\& Harrison, 2019).

Other soil properties and their correlation with SOC The forest soil had significantly higher cation exchange capacity (CEC) than the agroforestry system and oil palm plantation, and slightly, but not significant, higher than the agricultural field (Table 3 ). The SOC content was strongly correlated positively with soil CEC, $r=0.77, p$-value $<0.001$ (Figure $5 \mathrm{~A})$. A similar result was also reported from a study in Latosol soil in Mato Grosso State, Brazil, that after 10 years of no-till management, increase of SOC was positively correlated $(r=$ 0.92) with CEC (Ramos, 2018). With higher CEC, the forest soil had more sites to bind cations such as K.

In this study, the forest soil also had the highest exchangeable $\mathrm{K}$ (Table 3 ), and the SOC was strongly correlated positively with exchangeable $\mathrm{K}, r=0.80, p$-value $<$ 0.001 (Figure 5B). Another study found that soil organic matter had more adsorption for $\mathrm{K}$ than mineral soil (Wang \& Huang, 2001). In this study, the exchangeable $\mathrm{Ca}$ in forest soil was lower than the agroforestry land, but not significantly different from that in the agricultural field and oil palm plantation (Table 3), and SOC was correlated negatively with soil exchangeable $\mathrm{Ca}, r=-0.74, p$-value $<0.01$ (Figure 5E). In the upper Yellow River of China, Guo et al., (2016) who studied SOC and soil inorganic carbon (SIC) reported a positive correlation between SIC and soluble $\mathrm{Ca}^{2+}$, but did not report the correlation between $\mathrm{SOC}$ and $\mathrm{Ca}$, presumably because SOC did not correlate with $\mathrm{Ca}$.

The forest soil had the highest $\mathrm{pH}$ and $\mathrm{pH}$ was positively correlated with SOC, but the correlation was weak, $r=0.45$, $p$-value $<0.01$ (Figure 5C). In another study, SOC had no correlation with $\mathrm{pH}$ in inceptisols soil. However, in ultisols soils SOC was negatively correlated with $\mathrm{pH}$, but the correlation was very weak, $r=-0.141$ (Farrasati et al., 2020).

The forest had higher $\mathrm{P}$ than the other land use types (Table 3), but SOC contents were not significantly correlated with $\mathrm{P}$. The SOC is part of soil organic matter which generally contributes $2080 \%$ to the P soil, depending on soil type, and it prevents the $\mathrm{P}$ being fixed by $\mathrm{Al}$ and $\mathrm{Fe}$ and becomes unavailable to plant (Murphy, 2015).

In this study, the forest had higher $\mathrm{N}$ than other land use types, but the SOC had no correlation with N. Farrasati et al. (2020) did not find any correlation between SOC with N in ultisols soil, but they found that SOC was positively correlated with $\mathrm{N}$ in inceptisols, although the correlation was weak, with $r=0.392$.

Table 3 Soil chemical properties in different land use types in the study sites

\begin{tabular}{lcccccc}
\hline \multicolumn{1}{c}{ Land use types } & $\mathrm{pH}$ & $\begin{array}{c}\mathrm{Ca} \\
\left(\mathrm{cmol} \mathrm{kg}^{-1}\right)\end{array}$ & $\begin{array}{c}\mathrm{K} \\
\left(\mathrm{cmol} \mathrm{kg}^{-1}\right)\end{array}$ & $\begin{array}{c}\mathrm{CEC} \\
\left(\mathrm{cmol} \mathrm{kg}^{-1}\right)\end{array}$ & $\begin{array}{c}\mathrm{P} \\
\left(\mathrm{mg} \mathrm{kg}^{-1}\right)\end{array}$ & $\mathrm{N}(\%)$ \\
\hline Forest & $5.29 \pm 0.28 \mathrm{a}$ & $0.79 \pm 0.32 \mathrm{a}$ & $0.45 \pm 0.05 \mathrm{a}$ & $25.36 \pm 0.54 \mathrm{a}$ & $11.04 \pm 1.50 \mathrm{a}$ & $0.30 \pm 0.05 \mathrm{a}$ \\
Agricultural field & $4.53 \pm 0.23 \mathrm{c}$ & $1.24 \pm 0.30 \mathrm{a}$ & $0.34 \pm 0.03 \mathrm{~b}$ & $22.86 \pm 0.96 \mathrm{a}$ & $3.24 \pm 1.01 \mathrm{c}$ & $0.21 \pm 0.10 \mathrm{a}$ \\
Oil palm plantation & $4.62 \pm 0.09 \mathrm{c}$ & $0.83 \pm 0.27 \mathrm{a}$ & $0.38 \pm 0.04 \mathrm{~b}$ & $15.21 \pm 3.65 \mathrm{~b}$ & $7.40 \pm 0.84 \mathrm{~b}$ & $0.19 \pm 0.02 \mathrm{a}$ \\
Agroforestry system & $4.98 \pm 0.30 \mathrm{~b}$ & $2.07 \pm 0.30 \mathrm{~b}$ & $0.27 \pm 0.02 \mathrm{c}$ & $13.50 \pm 1.47 \mathrm{~b}$ & $5.58 \pm 1.64 \mathrm{~b}$ & $0.25 \pm 0.04 \mathrm{a}$ \\
\hline
\end{tabular}

Note: The values of $\mathrm{pH}$ were average of values from samples taken at 3 depths: $0-10 \mathrm{~cm}, 10-20 \mathrm{~cm}$ and $20-30 \mathrm{~cm}$, but the values of other chemical properties were only from samples of $0-10 \mathrm{~cm}$. Different letters following values in the same column indicate significant differences among the values $(p$-value $<0.05)$, determined with Fisher's LSD test. 


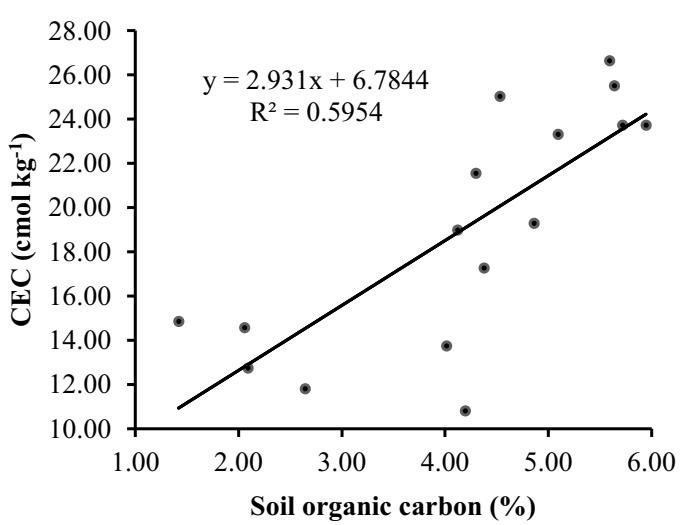

A

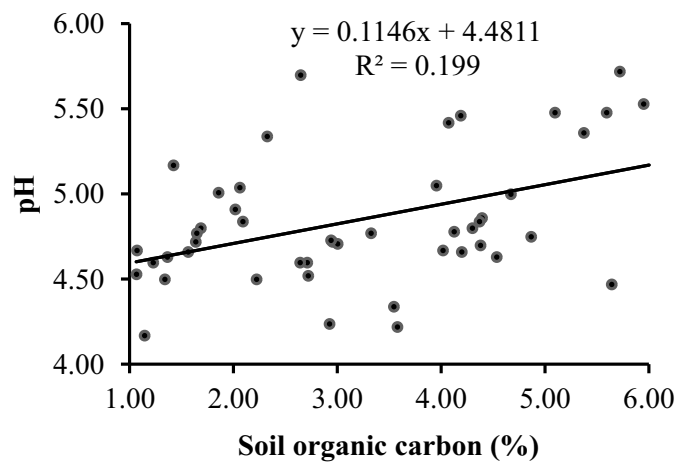

C

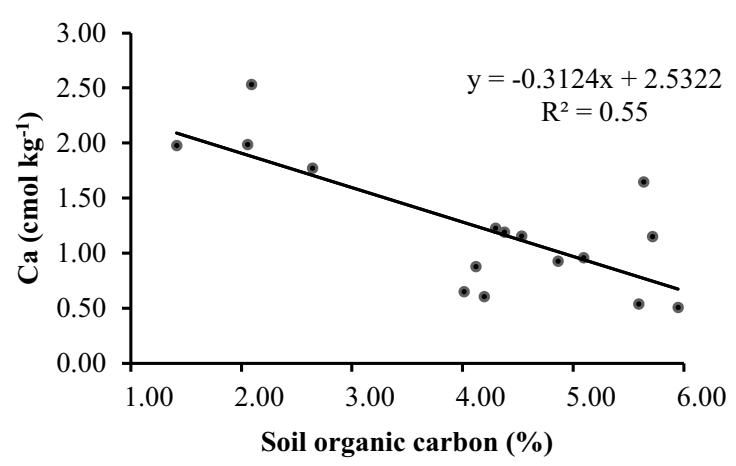

$\mathbf{E}$

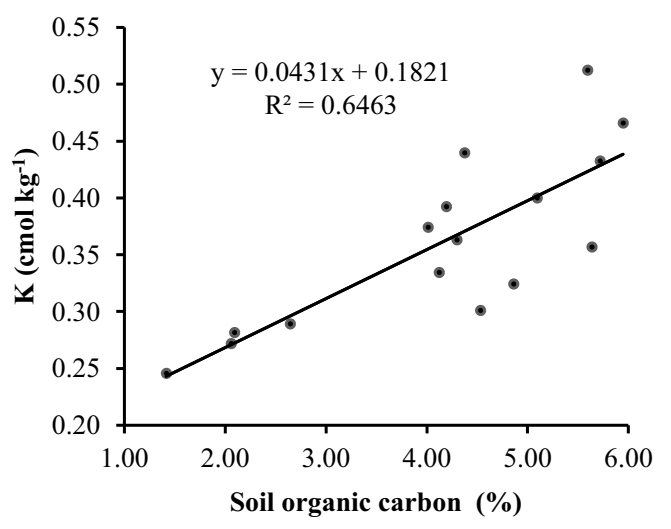

B

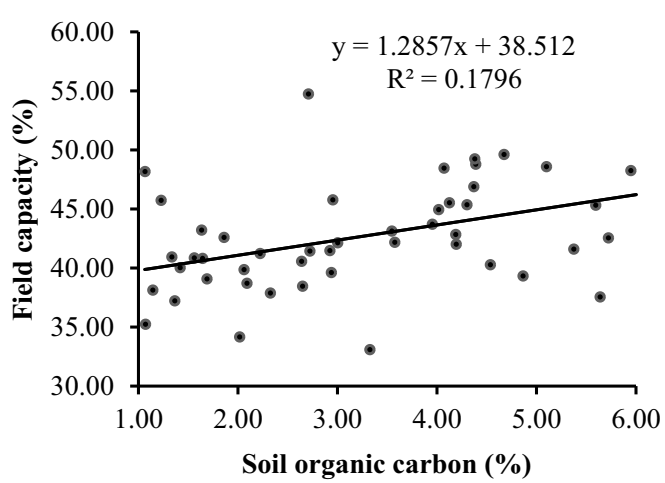

D

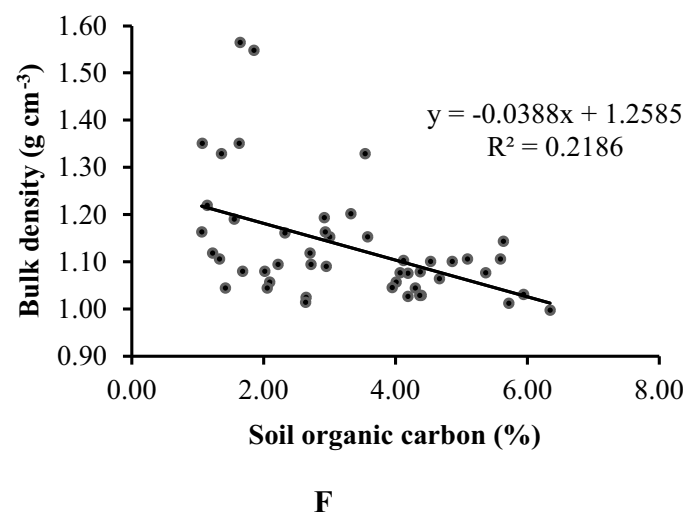

Figure 5 Soil properties having significant correlation with SOC, i.e., A) cation exchange capacity, B) potassium, C) pH, D) field capacity, E) calcium, and F) bulk density.

Soil physical properties and their correlation with SOC Soil bulk density varied with land use types and soil depths (Table 4 and Table 5). The bulk density in the forest was significantly lower than in the agricultural field and agroforestry land, but not significantly different from that in the oil palm plantation. Soil bulk density was the highest in the deep soil layer, while the SOC was the highest in the top layer. Bulk density was negatively correlated with the SOC but the correlation was weak, $r=-0.47, p$-value $<0.01$ (Figure 5F). In the tropical plain of Cameroon, the SOC is also negatively correlated with bulk density (Kome et al., 2021). The increased SOC may increase soil aggregate stability, reduce compaction, and lower the soil bulk density (McCauley et al., 2017).

The field capacity of the forest soil was significantly higher than in the agricultural field and agroforestry land, but not significantly different from the oil palm plantation. Soil organic carbon had positive correlation with field capacity, but the correlation was weak, $r=0.42, p$-value $<0.01$ (Figure 5D). In this study, the available water capacity was 
not determined because the laboratory could not do it, so only the field capacity was measured. A positive correlation between available water capacity and the SOC was found in several soils under different vegetation types in Bengkulu Province, Indonesia (Hermawan et al., 2020). In general, soil organic matter was known to increase plant available water by 2 to $3 \mathrm{~mm}$ per $10 \mathrm{~cm}$ for each $1 \%$ increase in soil organic carbon, depending on soil type (Murphy, 2015). Another study found that the relation of SOC and water retention was contradictory (Rawls et al., 2003). At low SOC, an increase in organic matter content increased water retention in sandy soils but decreased it in fine-textured soils. At high SOC, an increase of SOC increased water retention in all soil types.

The soil texture in the study sites was mostly sandy clay loam (Table 6). Soil with loam texture was found only in the top layer of the agroforestry system, clay texture only in the lowest layer of the forest, and clay loam texture only in the lowest layer of the agroforestry land. The forest soil had relatively higher clay content than the other land use types, but the difference was not significantly significant (Table 4). The clay content was not significantly different among soil depths, but there was a tendency that clay increased with the increasing depth (Table 5). Clay content was not correlated with SOC.

\section{Conclusion}

Forest had the highest SOC among the land use types, so if forest is converted to other land uses, the SOC decreases. Higher litter biomass in the forest floor was presumably the cause of higher SOC because litter biomass was positively correlated with SOC. The agricultural land, which was left fallow and occasionally received manure, ranked second in SOC and litter biomass.

Table 4 Soil physical properties in different land use types in the study sites

\begin{tabular}{lccc}
\hline Land use types & \multicolumn{3}{c}{ Physical properties } \\
\cline { 2 - 4 } & Bulk density $\left(\mathrm{g} \mathrm{cm}^{-3}\right)$ & Field capacity (\%) & Clay $(\%)$ \\
\hline Forest & $1.05 \pm 0.03 \mathrm{a}$ & $46.54 \pm 0.03 \mathrm{a}$ & $36.60 \pm 9.40 \mathrm{a}$ \\
Agricultural field & $1.17 \pm 0.09 \mathrm{~b}$ & $41.32 \pm 0.03 \mathrm{~b}$ & $30.51 \pm 14.92 \mathrm{a}$ \\
Oil palm plantation & $1.09 \pm 0.05 \mathrm{a}$ & $44.53 \pm 0.04 \mathrm{a}$ & $32.35 \pm 11.31 \mathrm{a}$ \\
Agroforestry system & $1.20 \pm 0.20 \mathrm{~b}$ & $38.60 \pm 0.03 \mathrm{~b}$ & $24.03 \pm 5.83 \mathrm{a}$ \\
\hline
\end{tabular}

Note: Numbers are mean and standard deviation. The values were the average of values from samples taken at 3 depths: $0-10 \mathrm{~cm}, 10-20 \mathrm{~cm}$, and $20-30 \mathrm{~cm}$. Different letters following values in the same column indicate significant differences among the values ( $p$-value $<0.05$ ), determined with Fisher's LSD test.

Table 5 Soil $\mathrm{pH}$ and physical properties at different depths in the study sites

\begin{tabular}{ccccc}
\hline Soil depth $(\mathrm{cm})$ & $\mathrm{pH}$ & Bulk density $\left(\mathrm{g} \mathrm{cm}^{-3}\right)$ & Clay $(\%)$ & Field capacity (\%) \\
\hline $0-10$ & $5.02 \pm 0.42 \mathrm{a}$ & $1.07 \pm 0.04 \mathrm{a}$ & $26.24 \pm 9.11 \mathrm{a}$ & $42.89 \pm 0.04 \mathrm{a}$ \\
$10-20$ & $4.86 \pm 0.41 \mathrm{~b}$ & $1.11 \pm 0.06 \mathrm{a}$ & $30.81 \pm 10.95 \mathrm{a}$ & $42.30 \pm 0.06 \mathrm{a}$ \\
$20-30$ & $4.68 \pm 0.24 \mathrm{~b}$ & $1.22 \pm 0.17 \mathrm{~b}$ & $35.57 \pm 12.75 \mathrm{a}$ & $42.90 \pm 0.04 \mathrm{a}$ \\
\hline
\end{tabular}

Note: Numbers are mean and standard deviation. Different letters following values in the same column indicate significant differences among the values $(p$-value $<0.05)$, determined with Fisher's LSD test.

Table 6 Soil texture in different land use types and depths in the study sites

\begin{tabular}{|c|c|c|c|c|}
\hline \multirow{2}{*}{ Land use types } & Sand & Clay & Silt & \multirow{2}{*}{ Texture class } \\
\hline & \multicolumn{3}{|c|}{$0-10 \mathrm{~cm}(\%)$} & \\
\hline Forest & 51.51 & 31.93 & 16.56 & Sandy clay loam \\
\hline Agricultural field & 48.00 & 26.53 & 25.47 & Sandy clay loam \\
\hline Oil palm plantation & 52.68 & 27.54 & 19.78 & Sandy clay loam \\
\hline \multirow[t]{2}{*}{ Agroforestry system } & 44.06 & 18.96 & 36.98 & Loam \\
\hline & \multicolumn{3}{|c|}{$10-20 \mathrm{~cm}(\%)$} & \\
\hline Forest & 49.68 & 33.67 & 16.65 & Sandy clay loam \\
\hline Agricultural field & 48.76 & 29.54 & 21.70 & Sandy clay loam \\
\hline Oil palm plantation & 45.03 & 36.55 & 18.42 & Sandy clay \\
\hline \multirow[t]{2}{*}{ Agroforestry system } & 40.20 & 23.48 & 36.31 & Sandy clay loam \\
\hline & \multicolumn{3}{|c|}{$20-30 \mathrm{~cm}(\%)$} & \\
\hline Forest & 39.68 & 44.21 & 16.11 & Clay \\
\hline Agricultural field & 46.46 & 35.47 & 18.07 & Sandy clay \\
\hline Oil palm plantation & 48.64 & 32.97 & 18.39 & Sandy clay loam \\
\hline Agroforestry system & 35.45 & 29.65 & 34.9 & Clay loam \\
\hline
\end{tabular}




\section{Recommendation}

Maintaining high litter biomass on the ground is essential to reduce SOC loss when a forest is converted to agricultural land. Therefore, crop residues should be returned, or manure should be added to the soil in the agricultural land..

\section{Acknowledgment}

This study was funded by the University of Bengkulu's research grant with a contract number 2073/UN30.15/PG/2020 and field sampling was helped by our students, i.e., Maruli, Nori, Yohan, Oki, and Andreas, while the soil analyses were done by Soil Laboratory staff, i.e., Zainal Arifin. All the supports were gratefully acknowledged.

\section{References}

Agus, F., Yusrial, \& Sutono, S. (2006a). Penetapan tekstur tanah. In In U. Kurnia, F. Agus, A. Adimihardja, \& A. Dariah (Eds.), Sifat fisik tanah dan metode analisisnya (pp. 43-62). Balai Besar Litbang Sumberdaya Lahan Pertanian.

Agus, F, Yustika, R. D., \& Haryati, U. (2006b). Penetapan berat volume tanah. In U. Kurnia, F. Agus, A. Adimihardja, \& A. Dariah (Eds.), Sifat fisik tanah dan metode analisisnya (pp. 25-34). Balai Besar Litbang Sumberdaya Lahan Pertanian.

[BSN] Badan Standardisasi Nasional. (2011). SNI-7724 Pengukuran dan penghitungan cadangan karbon. Jakarta: BSN

Deng, L., Zhu, G., Tang, Z., \& Shangguan, Z. (2016). Global patterns of the effects of land-use changes on soil carbon stocks. Global Ecology and Conservation, 5, 127-138. https://doi.org/10.1016/j.gecco.2015.12.004

Eviati, \& Sulaiman. (2009). Petunjuk teknis analisis kimia tanah, tanaman, air dan pupuk. Bogor: Balai Penelitian Tanah, Departemen Pertanian.

[FAO] Food and Agriculture Organization. (2017). Soil organic carbon: The hidden potential. Food and Agriculture Organization.

Farrasati, R., Pradiko, I., Rahutomo, S., Sutarta, E. S., Santoso, H., \& Hidayat, F. (2020). C-organik tanah di perkebunan kelapa sawit Sumatera Utara: Status dan hubungan dengan beberapa sifat kimia tanah. Jurnal Tanah dan Iklim, 43(2), 157-165. https://doi.org/ 10.21082/jti.v43n2.2019.157-165

Franzluebbers, A. J. (2021). Soil organic carbon sequestration calculated from depth distribution. Soil Science Society of America Journal, 85(1), 158-171. https://doi.org/10.1002/saj2.20176

Fusaro, C., Sarria-Guzmán, Y., Chávez-Romero, Y.A., LunaGuido, M., Muñoz-Arenas, L. C., Dendooven, L., ..., \& Navarro-Noya, Y. E. (2019). Land use is the main driver of soil organic carbon spatial distribution in a high mountain ecosystem. PeerJ, 7, e7897. https://doi.org/ $10.7717 /$ peerj.7897

Gross, C. D., \& Harrison, R. B. (2019). The case for digging deeper: Soil organic carbon storage, dynamics, and controls in our changing world"2279.24.

Guo, Y., Wang, X., Li, X., Wang, J., Xu, M., \& Li, D. (2016). Dynamics of soil organic and inorganic carbon in the cropland of upper Yellow River Delta, China. Scientific Reports, 6(1), 36105. https://doi.org/10.1038/srep36105

Hermawan, B., Suhartoyo, H., Sulistyo, B., Murcitro, B. G., \& Herman, W. (2020). Diversity of soil organic carbon and water characteristics under different vegetation types in northern Bengkulu, Indonesia. Biodiversitas, 21(5), 1793-1799. https://doi.org/10.13057/biodiv/d210504

Jendoubi, D., Liniger, H., \& Speranza, C. I. (2019). Impacts of land use and topography on soil organic carbon in a Mediterranean landscape (north-western Tunisia). SOIL, 5(2), 239-251. https://doi.org/10.5194/soil-5-239-2019

Kadlec, V., Holubík, O., Procházková, E., Urbanová, J., \& Tippl, M. (2012). Soil organic carbon dynamics and its influence on the soil erodibility factor. Soil and Water Research, 7(3), 97-108. https://doi.org/10.17221/3/2012 -SWR

Kessler, M., Hertel, D., Jungkunst, H. F., Kluge, J., Abrahamczyk, S., Bos, M., ..., \& Tscharntke, T. (2012). Can joint carbon and biodiversity management in tropical agroforestry landscapes be optimized? PLoS ONE, 7(10), e47192. https://doi.org/10.1371/journal.pone.0047192

Khasanah, N., van Noordwijk, M., Ningsih, H., \& Rahayu, S. (2015). Carbon neutral? No change in mineral soil carbon stock under oil palm plantations derived from forest or non-forest in Indonesia. Agriculture, Ecosystems \& Environment, 211, 195-206. https://doi.org/10.1016/ j.agee.2015.06.009

Kome, G. K., Enang, R. K., \& Yerima, B. P. K. (2021). Soil organic carbon distribution in a humid tropical plain of Cameroon: Interrelationships with soil properties. Applied and Environmental Soil Science, 2021, 1-18. https://doi.org/10.1155/2021/6052513

Kong, A. Y. Y., Six, J., Bryant, D. C., Denison, R. F., \& van Kessel, C. (2005). The relationship between carbon input, aggregation, and soil organic carbon stabilization in sustainable cropping systems. Soil Science Society of America Journal, 69(4), 1078-1085. https://doi.org/ $10.2136 /$ sssaj2004.0215

Lal, R. (2020). Managing soils for negative feedback to climate change and positive impact on food and nutritional security. Soil Science and Plant Nutrition, 66(1), 1-9. https://doi.org/10.1080/00380768.2020. 1718548

Li, M., Xiong, Y., \& Cai, L. (2021). Effects of biochar on the 
soil carbon cycle in agroecosystems: An promising way to increase the carbon pool in dryland. IOP Conference Series: Earth and Environmental Science, 693(1), 012082. https://doi.org/10.1088/1755-1315/693/1/012 082

Mackey, B., Kormos, C. F., Keith, H., Moomaw, W. R., Houghton, R. A., Mittermeier, R. A., ..., \& Hugh, S. (2020). Understanding the importance of primary tropical forest protection as a mitigation strategy. Mitigation and Adaptation Strategies for Global Change, 25(5), 763-787. https://doi.org/10.1007/s11027-019-09891-4

McCauley, A., Jones, C., \& Olson-Rutz, K. (2017). Nutrient management module 08: Soil $\mathrm{pH}$ and organic matter. Montana State University Extension. http://msuextension.org/publications/AgandNaturalRes ources/NM8.pdf

Minasny, B., Malone, B. P., McBratney, A. B., Angers, D. A., Arrouays, D., Chambers, A., ..., \& Winowiecki, L. (2017). Soil carbon 4 per mille. Geoderma, 292, 59-86. https://doi.org/10.1016/j.geoderma.2017.01.002

Muchane, M. N. (2020). Agroforestry boosts soil health in the humid and sub-humid tropicsA meta-analysis. Agriculture, Ecosystem and Environment, 295, 106899. https://doi.org/10.1016/j.agee.2020.106899

Murphy, B. (2015). Key soil functional properties affected by soil organic matter - Evidence from published literature. IOP Conference Series: Earth and Environmental Science, 25, 012008. https://doi.org/ 10.1088/1755$1315 / 25 / 1 / 012008$

Namirembe, S., Piikki, K., Sommer, R., Söderström, M., Tessema, B., \& Nyawira, S. (2020). Soil organic carbon in agricultural systems of six countries in East Africa - A literature review of status and carbon sequestration potential. South African Journal of Plant and Soil, 37(1), 35-49. https://doi.org/10.1080/02571862.2019. 1640296

Navarro-Pedreño, J., Almendro-Candel, M. B., \& Zorpas, A. A. (2021). The increase of soil organic matter reduces global warming, myth or reality? Sci, 3(1), 18. https://doi.org/10.3390/sci3010018

Oldfield, E. E., Bradford, M. A., \& Wood, S. A. (2019). Global meta-analysis of the relationship between soil organic matter and crop yields. Soil, 5, 15-31. https://doi.org/10.5194/soil-5-15-2019

Ravindranath, N. H., \& Ostwald, M. (2008). Carbon inventory methods handbook for greenhouse gas inventory, carbon mitigation and roundwood production projects. Netherlands: Springer. https://doi.org/10.1007/ 978-1-4020-6547-7
Rawls, W. J., Pachepsky, Y. A., Ritchie, J. C., Sobecki, T. M., \& Bloodworth, H. (2003). Effect of soil organic carbon on soil water retention. Geoderma, 116(1-2), 61-76. https://doi.org/10.1016/S0016-7061(03)00094-6

Signor, D., Deon, M. D., Camargo, P. B. de, \& Cerri, C. E. P. (2018). Quantity and quality of soil organic matter as a sustainability index under different land uses in Eastern Amazon. Scientia Agricola, 75(3), 225-232. https://doi.org/10.1590/1678-992x-2016-0089

Soto-Pinto, L., Anzueto, M., Mendoza, J., Ferrer, G. J., \& de Jong, B. (2010). Carbon sequestration through agroforestry in indigenous communities of Chiapas, Mexico. Agroforestry Systems, 78(1), 39-51. https://doi.org/10.1007/s10457-009-9247-5

Steel, R. G. D., \& Torie, J. H. (1980). Principles and procedures of statistics. A biometrical approach (2nd ed.). McGraw-Hill Book Company.

Stella, T., Mouratiadou, I., Gaiser, T., Berg-Mohnicke, M., Wallor, E., Ewert, F., \& Nendel, C. (2019). Estimating the contribution of crop residues to soil organic carbon conservation. Environmental Research Letters, 14(9), 094008. https://doi.org/10.1088/1748-9326/ab395c

Sudirman, Sutono, S., \& Juarsa, I. (2006). Penetapan retensi air tanah di laboratorium. In Sifat Fisik Tanah dan Analisisnya. Balai Besar Litbang Sumberdaya Lahan Pertanian.

van Straaten, O., Corre, M. D., Wolf, K., Tchienkoua, M., Cuellar, E., Matthews, R. B., \& Veldkamp, E. (2015). Conversion of lowland tropical forests to tree cash crop plantations loses up to one-half of stored soil organic carbon. Proceedings of the National Academy of Sciences, 112(32), 9956-9960. https://doi.org/10.1073/ pnas. 1504628112

Wang, F. L., \& Huang, P. M. (2001). Effects of organic matter on the rate of potassium adsorption by soils. Canadian Journal of Soil Science, 81(3), 325-330. https://doi.org/10.4141/S00-069

Wasis, B. (2012). Soil properties in natural forest destruction and conversion to agricultural land, in Gunung Leuser National Park, North Sumatera Province. Jurnal Manajemen Hutan Tropika, 18(3), 206-212. https://doi.org/10.7226/jtfm.18.3.206

Zhou, W., Han, G., Liu, M., Zeng, J., Liang, B., Liu, J., \& Qu, R. (2020). Determining the distribution and interaction of soil organic carbon, nitrogen, $\mathrm{pH}$ and texture in soil profiles: A case study in the Lancangjiang River Basin, Southwest China. Forests, 11(5), 532. https://doi.org/ 10.3390/f11050532 